\title{
STUDY OF THE TERMS OF STORAGE OF MEAT PASTE OF FUNCTIONAL APPOINTMENT
}

\author{
O. Moskalyuk \\ National University of Food Technologies
}

\begin{tabular}{l} 
Key words: \\
Paste \\
Functional products \\
Shelf life \\
Microbiological \\
parameters \\
\multicolumn{1}{c}{ Article history: } \\
Received 02.03.2018 \\
Received in revised form \\
16.03.2018 \\
Accepted 06.04.2018 \\
\hline
\end{tabular}

Corresponding author:

O. Moskalyuk

E-mail:

npnuht@ukr.net

\begin{abstract}
The article presents the results of research of microbiological parameters of developed functional pates using fungal raw materials and phytocomplex of propagated grain of oat, barley, wheat and maize in order to confirm the safety and quality of the product when extending its expiration date.
\end{abstract}

Food safety and stability of meat pates during storage are important and necessary requirements for both consumers and producers, which depend on many factors (peculiarities of basic and auxiliary raw materials, sanitary and technical condition of equipment, correctness of carrying out of technological operations, preservation of necessary modes, etc.).

The issue of maintaining quality characteristics throughout the entire period of storage and sale, as well as the possibility of increasing it remains open. The impact of the environment on products and raw materials is due to many factors: chemical and biochemical (effects of oxygen and surface moisture, enzymes undergoing chemical transformation, entering and accumulation of undesirable substances, etc.), physical and physical-chemical (effects of temperature, ultraviolet, water activity, etc., biological (activity of microand macroorganisms).

To determine the influence of the proposed plant components on the expiration date of meat pates, bacteriological studies were carried out: the number of mesophilic aerobic and facultative-enaerobic microorganisms (MAFAM), bacteria of the intestinal stem group (BGKP), sulfitreducing clostridia, pathogenic flora, including bacteria of the genus Salmonellae, which characterize the safety of meat pates for consumption.

When studying microbiological parameters of patch products during 6 days at a temperature of $0 \ldots 4^{\circ} \mathrm{C}$ it was found that the dynamics of microflora in the control and experimental samples is practically the same and the number of microorganisms in them did not exceed the allowable norms for this type of product (no more than $1 \cdot 10^{3}$ in $1 \mathrm{~g}$ ).

DOI: $10.24263 / 2225-2924-2018-24-2-27$ 


\title{
ДОСЛІДЖЕННЯ ТЕРМІНІВ ЗБЕРІГАННЯ М'ЯСНИХ ПАШТЕТІВ ФУНКЦІОНАЛЬНОГО ПРИЗНАЧЕННЯ
}

\author{
О.Є. Москалюк
}

Національний університет харчових технологій

У статті наведено результати досліджень мікробіологічних показників розроблених паштетів функиіонального призначення з використанням грибної сировини та фітокомплексу пророщених зерен вівса, ячменю, пшениці та кукурудзи з метою підтвердження безпечності та якості продукту при подовженні термінів придатності.

Харчова безпека і стійкість м'ясних паштетів при зберіганні - ие важливі та необхідні вимоги як для споживачів, так $і$ для виробників, які залежать від багатьох факторів (особливостей основної та допоміжної сировини, санітарного й технічного стану обладнання, правильності проведення технологічних операчій, збереження необхідних режимів тощо).

Питання збереження якісних характеристик упродовж усього строку зберігання і реалізаиії, а також можливості його збільшення лишається відкритим. Вплив навколишнього середовища на продукти та сировину обумовлений безліччю факторів: хімічними та біохімічними (вплив кисню повітря і поверхневої вологи, хімічні перетворення під дією ферментів, потрапляння та накопичення небажаних речовин тощо), фізичними та фізикохімічними (вплив температури, ультрафіолету, активності води тощо), біологічними (діяльність мікро- і макроорганізмів).

Для визначення впливу внесення запропонованих рослинних компонентів на термін придатності м'ясних паштетів були проведені бактеріологічні дослідження: кількість мезофільних аеробних і факультативно-енаеробних мікроорганізмів (МАФАМ), бактерій групи кишкової палички (БГКП), сульфітредукуючих клостридій, патогенної флори, в тому числі бактерій роду Salmonellae, які характеризують безпечність м'ясних паштетів до споживання.

При дослідженні мікробіологічних показників паштетних виробів протягом 6 діб при температурі $0 \ldots 4^{\circ} \mathrm{C}$ було з'ясовано, що динаміка розвитку мікрофлори в контрольному та експериментальних зразках практично однакова і кількість мікроорганізмів у них не перевищувала допустимі норми для даного виду продукту (не більше $1 \cdot 10^{3}$ в 1 г).

Ключові слова: паштет, функиіональні продукти, термін придатності, мікробіологічні показники.

Постановка проблеми. Важливою соціальною проблемою в Україні є поліпшення структури харчування населення за рахунок підвищення біологічної цінності й удосконалення асортименту харчової продукції. У раціонах харчування населення спостерігається дефіцит повноцінних білків, поліненасичених жирних кислот, вітамінів, мінеральних елементів, харчових волокон тощо. В концепції «здорового» харчування особлива роль відводиться про- 
дуктам функціонального призначення як стратегічному напряму розвитку харчової промисловості. Їх одержують за інноваційними технологіями і розглядають не тільки як джерела пластичних речовин та енергії, але й як складний немедикаментозний комплекс, що відповідає фізіологічним потребам організму людини та має яскраво виражені лікувальні профілактичні або оздоровчі властивості. Поліпшити ситуацію може максимальне залучення біологічно активних компонентів при розробці нових продуктів харчування (комбінування сировинних інгредієнтів 3 урахуванням сучасних досягнень нутриціологіі).

Харчова продукція, особливо м'ясна, $\epsilon$ необхідним елементом для забезпечення якісного та повноцінного життя населення. Однак нарощення виробництва харчових продуктів не вирішує всіх проблем, пов'язаних із якістю, безпечністю, екологічністю, практичністю. Більшість проблем вирішуються завдяки вдосконалених або принципово нових технологій виробництва, що дає змогу отримувати продукцію відповідної якості.

Проте питання збереження якісних характеристик впродовж усього строку зберігання і реалізації, а також можливості його збільшення лишається відкритим. Вплив навколишнього середовища на продукти та сировину обумовлений безліччю факторів: хімічними та біохімічними (вплив кисню повітря i поверхневої вологи, хімічні перетворення під дією ферментів, потрапляння та накопичення небажаних речовин тощо), фізичними та фізико-хімічними (вплив температури, ультрафіолету, активності води тощо), біологічними (діяльність мікро- і макроорганізмів).

Аналіз останніх досліджень і публікацій. На сьогодні однією 3 найважливіших проблем суспільства $\epsilon$ мінімізація негативного впливу довкілля на людину. Порушена екологія та деформований раціон харчування призводить до зниження загальної резистентності організму. Традиційне харчування не забезпечує високого профілактичного ефекту та може привести до виникнення нутрієнтно дефіцитних станів організму. [1]. За оцінкою фахівців здоров'я населення лише на $8-12 \%$ залежить від системи охорони здоров'я, в той час як частка впливу на нього соціально-економічних чинників і способу життя, в тому числі фактор харчування, досягає від 52 до 56\%. Правильно побудоване відповідно фізіолого-гігієнічних вимог, харчування забезпечує нормальний перебіг обміну речовин, підтримує високий рівень функціональної здатності найважливіших систем організму і таким чином сприяе загальному зміцненню здоров'я, продовженню життя і активному творчому його періоду [2;3].

Одним із провідних напрямків наукових досліджень останнього десятиріччя є розробка харчових продуктів функціонального призначення. Це спонукає розробників до пошуку нових нетрадиційних сировинних інгредієнтів із високим вмістом біологічно активних речовин [3-5].

Сучасні м'ясні продукти створюють за принципом харчової комбінаторики, шляхом кількісного підбору основної сировини, інгредієнтів, харчових добавок. Це забезпечує формування бажаних органолептичних, фізико-хімічних, технологічних властивостей, а також заданий рівень харчової, біологічної й енергетичної цінності готових виробів. Одним із оптимальних вирішень 
проблеми оздоровлення харчування $є$ виробництво паштетів, які часто рекомендують при захворюваннях кишківника, особливо при гастритах. Адже в паштеті містяться інгредієнти тваринного і рослинного походження у легкодоступній для травних ферментів формі. Вибір компонентів рецептури м'ясного паштету обумовлений їх хімічним складом, функціональними і технологічними властивостями та енергетичною цінністю. М'ясні паштети, де м'ясо та субпродукти $є$ основними інгредієнтами, користуються попитом завдяки високій харчовій цінності, приємному специфічному смаку і ніжній консистенції [6-8].

Метою статті $є$ розроблення рецептур і розширення асортименту паштетів 3 використанням рослинних компонентів, багатих функціональними нутрієнтами, та дослідження показників безпеки готових виробів.

Викладення основних результатів дослідження. Як рецептурні компоненти розроблених паштетів запропоновано використання м'яса та субпродуктів птиці, грибної сировини та фітокомплексу пророщених зерен злакових культур. На початковому етапі розроблення інноваційного продукту були досліджені функціонально-технологічні показники рослинних добавок та їх вплив на структурно-механічні показники м'ясного фаршу для паштету. Розроблена технологія м'ясних паштетів функціонального призначення передбачає внесення масової частки рослинних компонентів у системі від $10 \%$ до $25 \%$ від загальної маси сировини [8; 9]. Однак використання нових нетрадиційних інгредієнтів при виробництві м'ясних паштетів обумовлює необхідність ретельного дослідження термінів зберігання і мікробіологічних показників. Викликано це насамперед фізико-хімічною активністю рослинних компонентів, їх високим вологовмістом і додатковою контамінованістю фаршу $[10 ; 11]$. Внесення рослинних компонентів у м'ясний фарш призводить до змін показників якості паштетів у процесі зберігання, зокрема бактеріологічних. Дослідження проводили на зразках паштетів у поліамідній оболонці, вироблених у промислових умовах. Грибну сировину та суміш пророщених зерен злакових культур вносили до складу паштетної маси на початку процесу кутерування за розробленою раніше рецептурою і за прийнятою технологією. Контролем були зразки паштетів, виготовлені згідно з ДСТУ 4432:2005 «Паштети м'ясні. Технічні умови». Як основну сировину в рецептурах паштетів використовували м'ясо та субпродукти з птиці, які мають дієтичні властивості.

М'ясо птиці засвоюється на 94-96\%, жирова тканина складає лише 5,2\% та характеризується великою кількістю поліненасичених жирних кислот. Печінка містить залізовміщуючі білки - ферин і феритин, які є джерелом заліза у синтезі гемоглобіну. Печінка багата азотистими екстрактивними речовинами, а також вітамінами, макро- та мікроелементами. Особливо велику кількість вона містить холіну, біотину, вітаміну А (50 мг\%), С (25-40 мг\%), ніацину, а також включає всі вітаміни групи В. Завдяки специфічному хімічному складу печінку широко використовують у лікувальному харчуванні при анемії, променевій хворобі, загальному ослабленні і зниженій кровотворній здатності організму. 
Гриби мають унікальний збалансований склад усіх біологічно цінних харчових компонентів: білків, жирів, вуглеводів, вітамінів, мікроелементів. Біологічно-активні речовини грибів сприяють нормалізації апетиту, підвищують імунітет, знижують рівень холестерину низької щільності, зменшують ризик інфаркту та запобігають появі атеросклерозу, впливають на розвиток пам'яті й активізують розумову діяльність людини. Гриби мають радіопротекторні властивості.

Також розроблені рецептури паштетів $з$ додаванням фітокомплексу злакових культур (пророщених зерен вівса, ячменю, пшениці та кукурудзи) для посилення лікувально-профілактичного ефекту.

Розроблені паштети були досліджені за органолептичними показниками, функціонально-технологічними та мікробіологічними показниками. Зразки, які містили грибну сировину, відрізнялись більш монолітною та гомогенною структурою і ніжним смаком порівняно 3 контрольним зразком. Зразки 3 фітокомплексом пророщених зерен мали хороші смакові якості, приємний смак і аромат, однорідну, ніжну консистенцію.

При розробленні паштетів 3 поєднанням м'ясної і рослинної сировини у заданому співвідношенні важливим $є$ дослідження впливу рослинних компонентів на фізико-хімічні показники готових продуктів. Дослідження хімічного складу показало, що за харчовою цінністю нові рецептури відповідають вимогам, які висуваються до цієї асортиментної групи. Паштети мають низьку масову частку жиру, високий вміст білків, що приводить до зниження енергетичної цінності.

Внесення нетрадиційної рослинної сировини у рецептури паштетів забезпечує високу вологозв'язуючу та вологоутримуючу здатності фаршів і сприяє створенню ніжної, соковитої консистенції готового продукту, збільшення виходу, зменшення втрат при термообробці.

Для визначення впливу внесених компонентів на термін придатності паштетів були проведені бактеріологічні дослідження, а саме: визначена кількість мезофільних аеробних і факультативно-енаеробних мікроорганізмів (МАФАМ,КУО), бактерій групи кишкової палички (БГКП), сульфітредукуючих клостридій, Staphylococcus aureus, L. Monocytogenes, в тому числі бактерій роду Salmonellae, що характеризує безпечність м'ясних виробів до споживання.

Мікробіологічні показники контрольного й експериментальних зразків здійснювали відповідно до санітарно-гігієнічних вимог на сировину та харчові продукти в процесі зберігання протягом 6 діб при температурі $0 \ldots 4^{\circ} \mathrm{C}$.

При дослідженні було з'ясовано, що динаміка розвитку мікрофлори в контрольному й експериментальних зразках практично однакова, кількість мікроорганізмів у них знаходилась на одному рівні і не перевищувала допустимі норми для даного виду продукту (не більше $1 \cdot 10^{3}$ в 1 г). Мікробіологічні показники розроблених паштетів з використанням грибної сировини та фітокомплексу пророщених зерен злакових культур представлені в табл. 1, 2. 
ХАРЧОВІ ТЕХНОЛОГЇ̈

Таблиия 1. Мікробіологічні показники паштетів з грибною сировиною

\begin{tabular}{|c|c|c|c|c|}
\hline \multirow{3}{*}{$\begin{array}{c}\text { Назва показників, згідно } \\
3 \text { ДСТУ 4432:2005 }\end{array}$} & \multicolumn{4}{|c|}{ Значення показників } \\
\hline & \multicolumn{3}{|c|}{ Тривалість зберігання, діб } & \multirow{2}{*}{$\begin{array}{c}\text { Відповідно до вимог ДСТУ } \\
\text { 4432:2005 }\end{array}$} \\
\hline & 1 & 3 & 6 & \\
\hline МАФАМ, КУО/Г & $6,05 \cdot 10^{2}$ & $7,3 \cdot 10^{2}$ & $8,11 \cdot 10^{2}$ & $1,0 \cdot 10^{3}$ \\
\hline БГКП & \multicolumn{3}{|c|}{ Не виявлено } & Не допускається \\
\hline $\begin{array}{l}\text { сульфіт-редукуючих } \\
\text { клостридій }\end{array}$ & \multicolumn{3}{|c|}{ Не виявлено } & Не дозволено \\
\hline $\begin{array}{c}\text { Staphylococcus aureus } \\
\text { в } 1 \text { г продукту }\end{array}$ & \multicolumn{3}{|c|}{ Не виявлено } & Не дозволено \\
\hline $\begin{array}{l}\text { L. Monocytogenes } \\
\text { в } 25 \text { г продукту }\end{array}$ & \multicolumn{3}{|c|}{ Не виявлено } & Не дозволено \\
\hline $\begin{array}{c}\text { Salmonella } \\
\text { в } 25 \text { г продукту }\end{array}$ & \multicolumn{3}{|c|}{ Не виявлено } & Не дозволено \\
\hline
\end{tabular}

Таблиця 2. Мікробіологічні показники паштетів з фітокомплексом пророщених зерен

\begin{tabular}{|c|c|c|c|c|}
\hline \multirow{2}{*}{$\begin{array}{c}\text { Назва показників, згідно } \\
\text { з ДСТУ 4432:2005 }\end{array}$} & \multicolumn{3}{|c|}{ Значення показників } \\
\cline { 2 - 4 } & \multicolumn{2}{|c|}{ Тривалість зберігання, діб } & $\begin{array}{c}\text { Відповідно до вимог ДСТУ } \\
4432: 2005\end{array}$ \\
\hline МАФАМ, КУО/г & $8,5 \cdot 10^{2}$ & $0,9 \cdot 10^{2}$ & $1,1 \cdot 10^{2}$ & $1,0 \cdot 10^{3}$ \\
\hline БГКП & \multicolumn{3}{|c|}{ Не виявлено } & Не допускається \\
\hline $\begin{array}{c}\text { сульфіт-редукуючих } \\
\text { клостридій }\end{array}$ & \multicolumn{2}{|c|}{ Не виявлено } & Не дозволено \\
\hline $\begin{array}{c}\text { Staphylococcus aureus } \\
\text { в 1 г продукту }\end{array}$ & \multicolumn{2}{|c|}{ Не виявлено дозволено } \\
\hline $\begin{array}{c}\text { L. Monocytogenes } \\
\text { в 25 г продукту }\end{array}$ & Не виявлено & Не дозволено \\
\hline $\begin{array}{c}\text { Salmonella } \\
\text { в 25 г продукту }\end{array}$ & Не виявлено & Не дозволено \\
\hline
\end{tabular}

Результати досліджень м’ясного паштету (табл. 1, 2) вказують на мікробіологічну стабільність (у межах допустимих норм), що свідчить про безпечність і придатність продукту до споживання.

\section{Висновки}

Розроблені рецептури м'ясних паштетів 3 використанням грибної сировини та фітокомплексу пророщених зерен злакових культур характеризуються високою харчовою цінністю, мають оптимізований хімічний склад i можуть бути запропоновані в раціонах харчування медичного спрямування. Комбінування сировини тваринного i рослинного походження не знижує органолептичних показників продукту, а в деяких випадках вони навіть вищі, ніж у контрольних зразках. При дослідженні мікробіологічних показників паштетів виявлено, що динаміка змін кількості мікрофлори незначна протягом шести діб зберігання, а кількість мікроорганізмів не перевищує допустимі норми для цього виду продукту.

\section{Література}

1. Пересічний M.I. Харчування людини і сучасне довкілля: теорія і практика / М.I. Пересічний, М.Ф. Кравченко, В.Н. Корзун, О.М. Григоренко // [Монографія]. Київ : КНТЕУ, 2003. - 526 с. 
2. Москалюк O.C. Розробка м'ясних геродієтичних продуктів - основа здорового харчування / О.Є. Москалюк, О.І. Гащук, О.А. Чернющок // Науковий вісник ЛНУВМБТ ім. С.3 Гжицького. Технічні науки. Серія «Харчові технології». — 2014. - Том 16, № (59).- Частина 4. - С. 43-48.

3. Трубина И.А. Функциональные продукты на м'ясний основе / И.А. Трубина // Ежеквартальный научно-практический журнал. - 2012. — № 4(8). - С. 46-48.

4. Lobo V. Free radicals, antioxidants and functional foods: Impact on human health / V. Lobo, A. Patil, A. Phatak, N. Chandra // Department of Botany, Birla College, Kalyan 421 304, Maharastra, India. - 2016. - P. 125-128.

5. Mari Niva Understandings of functional foods and healthy eating among health-oriented finns / Mari Niva // All foods affect health. — 2016. — P. 384 -393.

6. Пешук Л.В. Розробка м'ясних геродієтичний продуктів - пріоритетний науковий напрямок / Л.В. Пешук, О.С. Москалюк, I.I. Гащук // Науковий журнал «Вісник Сумського НАУ» серія «Тваринництво», Суми. — 2014. — № 2/2(25). — С. 187-190.

7. Москалюк О.С. Інноваційний м'ясний продукт / О.С. Москалюк, Л.В. Пешук, О.І. Гащук // Харчова промисловість. -Київ : НУХТ, 2015. — № 17. - С. $64-67$.

8. Солецька А.Д. Розробка рецептури м'ясних паштетів лікувально-профілактичного призначення / А.Д. Солецька, А.В. Асауляк // Наукові праці ОНАХТ. - 2011. Вип. 40(2). - С. 205-207.

9. Пасічний В.M. Дослідження термінів зберігання комбінованих м'ясопродуктів 3 грибним напівфабрикатом / В.М. Пасічний, Ю.А. Ястреба // Обладнання та технології харчових виробництв. — 2011. — № 27. - С. 135-140.

10. Москалюк O.E. Разработка мясного паштета повышенной биологической ценности / О.Е. Москалюк, А.И. Гащук, Л.В. Пешук, О.А. Чернюшок // Пищевая промышленность: наука и технологи. - Минск, 2017. —№ 4(38). - С. 9-13.

11. Москалюк O.Є. Розроблення паштетів з використанням фітокомплексу злакових культур «СНОІСЕ / O.С. Москалюк, О.I. Гащук // Наукові праці Національного університету харчових технологій. — 2017. - Т. 23, № 4. - С. $238-243$. 